\title{
DEVELOPMENT OF THE RUSSIAN AGRO-INDUSTRIAL COMPLEX IN THE FOOD SECURITY CONTEXT
}

\author{
Svetlana Eshugova \\ Faculty of Economics and service, Maykop State Technological University, \\ Maykop, Russia
}

CMESTE

JEL Category: F63, H12, 011, Q01, R11

\begin{abstract}
The article examines the topical issues related to the problems of agricultural products import substitution in Russia under the sanctions, and as a result, food and economic safety ensuring. The importance of state support for agribusiness in terms of import substitution and the relevance of regulatory documents adopted by the RF Government aimed at strengthening Russia's participation in international cooperation in the field of agriculture and fishery as well as food safety are determined. The article analyzes the industries with the maximum potential of import substitution. It is noted that the critical points of import substitution in the production of food products are in the sphere of dairy industry and $10 \%$ reduction of Russian agriculture meat imports can be made up through the development of poultry production, and probably pork production. As for beef, import substitution here requires an increase in the number of cattle, which has been declining in recent years. The potential of import substitution (resource, labor, property, financial and others) of a geographically separate formation (region) is considered in detail, the import substitution strategy based on the development of production in general, agricultural products quality and safety improvement, modern innovative technologies used in the agro-industrial complex enterprises are designated. The role of gradually developing import substitution process, which in the future will contribute to the growth of employment and, as a consequence, to the reduction of unemployment and improvement of living standards, growth in demand for agricultural products of domestic production, which in turn contributes to the conservation of foreign exchange earnings within the country and to the growth of foreign exchange reserves and improvement of the country's trade balance. The need for the transition from the import oriented development to import substitution phase in the Russian regions is grounded. The conclusion is made about the need for an integrated approach to the implementation of a coordinated program of activities aimed to protect domestic producers by substituting imported food products with domestic goods.
\end{abstract}

Keywords: import substitution strategy, agricultural products, competitiveness, resource potential.

\section{INTRODUCTION}

The existing geopolitical situation, in particular the sanctions of the EU, the USA and a number of

Address of the author: Svetlana Eshugova 䤵: eshug.sv@yandex.ru other countries towards Russia, dictates the need to adapt the agro-industrial complex (AIC) development strategy to the new conditions, 
particularly in the aspect of import economic relations. First of all, it is necessary to interpret the category of "import substitution". It is a system of methods to reduce import dependence aimed at overcoming actual or potential shortage of imported products. It allows to improve the stability of national production, creates additional demand for domestic resources, reduces the risks of goods supply (Semykin, Safronov, \& Terekhov, 2014). To achieve this aim fully, a number of measures are required that would ensure the profitability of import substitution for the whole range of key actors: the state, the society and the business. Development of territorial (regional) programs of import substitution should be the basis of this set of measures (Gusakova, 2014).

On October 2, 2014 the prime minister Dmitry Medvedev signed the Order No. 1948-r "On the approval of the plan of measures ('road map') to assist import substitution in agriculture for 20142015-s" (TPP-Inform, 2014).

The approved "road map" contains a complex of measures (including development of regulations) aimed at the achievement of import substitution indicators established in the State program of the development of agriculture and regulation of agricultural markets, raw materials and food stuff for 2013-2020-s and the State program "Development of Fishery Complex". The plan provides improvement of the mechanisms of customs and tariff regulation of the import of main types of agricultural, fish and other products from the water biological resources taking into account Russian membership in the WTO and in the Customs union.

The "road map" includes measures to increase the efficiency of agricultural land use and improvement of the state veterinary and phytosanitary control (supervision), including measures to create the state automated information system of the early notification in case of detection of veterinary and sanitary dangerous goods.

\section{ANALYSIS}

The made decisions are directed to the activization of participation of Russia in the international cooperation in the field of agriculture and fishery, and food safety. Realization of the provisions of the plan will allow to provide the increase in agricultural production, raw materials and food stuff and decrease in the dependence of the domestic food market on import deliveries of meat from 21.6 to $7.7 \%$, milk and dairy products from 23.6 to $16.6 \%$, vegetables from 14.6 to $10.1 \%$ by 2020 .

The dairy branch is one of the most sensitive to import. If the volume of import of whole-milk products is rather small, then, for example, that of cheese reaches a half, of butter - $40 \%$ (Kostrova, 2014). With the introduction of response sanctions the dairy branch is in the center of attention at all government meetings on import substitution. However, the situation will most likely not change in the shortest possible time, since the increase in the productive herd of dairy cows needs time. Therefore, despite all optimistic statements that the Russian producers will be able to fill the market with domestic products quite fast, nevertheless import from the countries not included in the prohibition list will still be necessary.

The potential of import substitution of a territorially isolated formation (region) is defined as a set of the resource potential, the institutional environment, the organizational capital and the volume of domestic demand. Resource potential is treated as a set of factors of production of the agents of the basing territory, and also mechanisms of their involvement and use in the public reproduction as an integral characteristic of the condition of the regional economy defining its abilities to the production of economic and social value. If the presence of resources in the regional economy acts as a necessary condition for the formation of its resource potential, then their complementarity, interaction and adequacy to the condition of the factors of internal and external environment of a territorial formation is its sufficient condition.

Effective realization of the resource capacity of the region is possible at the presence of organizational routines, procedures and algorithms of actions and processes, as well as the principles of formation of communications between the residents and (or) nonresidents of the regional economy, and also the ability to create, integrate and reconfigure these routines, procedures, algorithms and principles. The structure and qualitative characteristics of the factors of production making the resource 
potential of a territorial formation define a type of economic activity concerning which the use of import substitution tools is expedient.

In spite of the region type defined on the basis of identification of the dominating tendency of development of labor potential, the positive steady dynamics of labor productivity acts as a necessary condition of application of import substitution strategy that provides decrease in a share of labor in expenses and increase of the importance of such factors as introduction of logistic models, existence of the enterprises and organizations carrying out basic and applied scientific researches and developments, degree of utilization of production capacities, volume of domestic demand. In turn, the steady growth of the last is provided due to the cumulative expenses including expenses of the state, directed to the stimulation of demand for domestic products and Russian export.

The capital belongs to the property potentials as a component of the resource potential of the regional economy and potential of import substitution. According to the official data, the coefficients of utilization of production capacities in 2014 made $66 \%, 64 \%$ and $56 \%$ for the sectors of production, processing and distribution respectively, at the same time $20 \%, 14 \%$ and $12 \%$ of capacities in these sectors are completely wornout (GKS, 2015).

Thus, a rather low level of free capacities and high degree of their deterioration are characteristic for the Russian economy that defines need for the considerable volume of investments to realize the import substitution strategy. At the same time in 2012 the specified sector achieved the post-crisis maximum of the level of loading and made $69.5 \%$, and was characterized by the additional growth of about $5 \%$ at its contribution into the RF GDP gain of 0.4 i.c. (Sberbank, 2015).

However, nowadays there is no potential demand for the gain of a cumulative product of the extracting sector. Thus, the high level of loading of production capacities and deterioration of the funds of this sector of the Russian economy can't provide the essential effect of import substitution. At the same time there are reserve free capacities in the processing sector the additional loading of which, according to expert estimates, can provide a gain of outputs for $2.5 \%$ that will make 0.3 i.c. of the RF GDP gain and 1.4 i.c. gain of industrial outputs. Thereby, a type of economic activity concerning which the use of instruments of import substitution can provide corresponding effect is defined by the state of the resource potential of a region.

Financial resources of the region as a component of the resource potential of the regional economy and potential of import substitution includes financial resources which the region and its residents possess, and also the resources which can be used to accomplish the functions of the regional governing bodies.

Federal and regional target programs and credit subsidizing are used as tools for the realization of the strategy of import substitution, and in the agroindustrial complex untied support of agricultural producers in the field of plant growing, compensation of a part of an interest rate for the investment credits (loans) to develop plant growing and processing, and also development of infrastructure and logistic providing of the markets of plant products, compensation of a part of an interest rate for short-term credits (loans) for the development of animal husbandry, processing and sales of products of animal husbandry, etc. have been used since 2013 .

According to the official data, profitability of agricultural organizations in 2013 made $7.3 \%$, without the subsidies this indicator is negative $5.6 \%$ (Sberbank, 2015). The pool of sources of financing of import substitution strategy includes Fund of the development of the industry, SC "Bank for the Development and Foreign Economic Affairs", its affiliated funds and banks, JSC "Russian Bank of Support of Small and Medium Business", JSC "Federal Corporation on the Development of Small and Medium Business (SMP Corporation) (the last provides financial guarantees for the sum up to $70 \%$ of the bank credit if the borrower doesn't have enough pledges on the corresponding project), etc. Development of the instruments of use of financial resources of pension funds and insurance companies for accurately structured criteria and guarantees of banks and/or state is obviously necessary.

Organizational resources of the region as a component of the resource potential of the regional economy and potential of import substitution are presented by a set of 
organizational and economic relations between residents and (or) nonresidents of the regional economy concerning allocation and re-allocation of the assets for the purpose of production, distribution, exchange and consumption of an added value. The structure of the organizational resources includes the objects of intellectual property and other intangible assets (including a territorial brand) used in the course of reproduction, the database, information systems, culture type, etc.

Institutes that have to prevent preservation of technical and technological base and stimulate food and process innovations, and also initiate replacement of critical import technologies that is a necessary condition for the effective functioning of system of food, military, etc. safety of the state act as components of import substitution potential.

The institutes preventing rent-oriented behavior of the officialdom of public authorities at making decisions on the directions of the public expenditures and development of federal and regional target programs and also the institutes causing compliance of the manufactured goods to the requirements of technical regulations and standards are among the institutional component of import substitution potential.

Further development of agriculture in the conditions of dependence on import has become a serious threat for food safety of Russia. It is impossible without strengthening the role of the state and support of this important sphere of economy.

One of such support instruments are non-tariff methods of regulation of the state foreign trade policy. The greatest distribution in international trade has been gained by the methods of quantitative restriction of import and export. Among them are: quoting; licensing; voluntary export restrictions and trade embargo.

So, according to the Decree of the President of the RF the food embargo in the form of total ban on the deliveries of beef, pork, fowl, fish, cheese, milk, fruit and vegetable products from Australia, Canada, the EU, the USA and Norway for a period of one year has been introduced since August 7 , 2014.

Thus, high import dependence of the country concerning some types of food stuff significantly reduces its food and economic safety because foreign purchases of food stuff and raw materials for their production in large volumes put additional pressure upon limited currency resources. It is obvious that importing agricultural food products, Russia in a way finances not domestic, but foreign producers, thereby weakening its own role in the world economy.

It should be noted that the strategy of import substitution in the agricultural sector of economy has to rely on the development of all production process, improvement of the quality and safety of food products, modern innovative technologies applied at the enterprises of agrarian and industrial complex.

At the same time step-by-step developing process of import substitution will promote the growth of employment of the population and, as a result, decrease in unemployment and increase of living standard; increase of the level of scientific and technical progress in the agrarian branch; strengthening of economic and food safety of the country; increase in the demand for agricultural products of domestic production that in turn stimulates the development of agrarian and industrial complex of the country, expansion of its production capacities; preservation of currency revenues within the country, growth of currency reserves and improvement of trade balance of the country.

The existing geopolitical situation dictates the need for and even inevitability of transition of Russia from import-oriented development to import substitution phase (Faltsman, 2015).

All the listed above import substitution factors, including sanctions, define its compulsory character that is not connected with growth of competitiveness of domestic products. Meanwhile, decline in quality and possible price growth will be a consequence of forced replacement of import by noncompetitive production.

Difference of foodstuff from other products consists in the fact that their import is limited not by American-European, but by Russian response sanctions. Besides, the world food stuff market satisfies primary requirements of the population therefore the food safety is the object of geopolitical, supranational value. 
In 2012 Russia satisfied the fourth part of consumption of meat and meat products due to the import. In the previous years the share of import was higher. It demonstrates that the Russian meat industry has entered an import substitution phase.

The most important reason of import substitution of meat and meat products was breakthrough of Russia in the field of fowl meat production which increased by 5.4 times - from 766 thousand tons in 2000 to 3625 thousand tons in 2012. At the same time the import of fowl reduced by $40 \%$ while deliveries to domestic market increased by 2.2 times. The import share in the deliveries decreased from $61 \%$ in 2000, to $17 \%$ in 2012 (Galeyev, Radosteva, \& Bartova, 2015).

It should be noted that intensive process of import substitution was taking place before the introduction of sanctions and that is one of the achievements of the AIC. At present the population of the country is almost completely provided with fowl, and its import falls under the Russian sanctions. Long-term forecasts till 2021 at zero import provide noticeable increase in the production of fowl the fourth part of which can be exported.

Peculiarity of the substitution of import of meat and dairy products from the EU countries is that it is partially feasible due to the deliveries from the third countries, including the Latin American countries (Radchenko, Sukhorukova, Parshina, \& Volkov, 2015).

As a result, critical points of import substitution in the production of foodstuff are in the sphere of the meat and dairy industry. The Russian agrarian and industrial complex can win back the tenpercentage reduction of import of meat planned above due to the development of production of fowl, and perhaps, pork. As for beef, import substitution demands increase in the number of cattle which has been reducing in recent years.

The reached high level of self-reliance in the production of grain (bread, grain), potatoes (the second bread), fowl and eggs (protein for poor) allows protecting the population from the possibility of hunger. But at the same time, according to some experts, if domestic production of meat and dairy products is not increased, the consumption of proteins of animal origin per capita will probably tend to decrease.

\section{CONCLUSION}

Critical points of future development of other basic foodstuff are not in the sphere of import substitution but mostly in the reorientation to export growth. The Russian agrarian and industrial complex has already made such change of a growth phase in grain production and production of fowl.

Thus, import substitution as a type of economic strategy and agro-industrial policy of the state is directed to the protection of a domestic producer by the substitution of the imported foodstuff with goods of national production. Increase of competitiveness of a domestic production by means of stimulation of technological modernization of production, increase of its efficiency and development of new competitive types of production with rather high added value has to become the result of import substitution.

\section{WORKS CITED}

Faltsman, B. K. (2015, Jan). Critical points of import substitution policy. Russian Journal of Entrepreneurship, 16(2), 241-262. Retrieved from https://bgscience.ru/com/lib/5227/

Galeyev, M. M., Radosteva, E., \& Bartova, E. (2015). Vozmozhnosti importozameshcheniya v sisteme prodovol'stvennoy bezopasnosti Rossii. Naukovedeniye, 7(3). Retrieved from http://naukovedenie.ru/PDF/88EVN315.pdf

GKS. (2015, May 15). Production indices by economic activity. Retrieved from Russian Federation Federal State Statistic Service: http://www.gks.ru/bgd/regl/b15_12/lssWWW.exe/stg/d01/1503.htm

Gusakova, E. (2014). Import substitution is a priority objective of the AIC development. Fundamentals of Economics, Management and Law, 18(6), 12-17. 
Kostrova, A. (2014, Aug 22). Prozhivom bez importa? Retrieved from Nevskoye Vremya: http://nvspb.ru/tops/projivem-bez-importa-55174

Radchenko, T., Sukhorukova, K., Parshina, Y., \& Volkov, A. (2015, Aug.). Prodovol'stvennoye embargo: importozameshcheniye i izmeneniye struktury vneshney torgovli. Byulleten' o razvitii konkurentsii(11), 24. Retrieved from http://ac.gov.ru/files/publication/a/6007.pdf

Sberbank. (2015, May 05). Analitika $i$ issledovaniya. Retrieved from Sberbank: https://www.sberbank.ru/ru/about/analytics

Semykin, V., Safronov, V., \& Terekhov, V. (2014). Import substitution as an effective tool for the optimal development of market economy. Bulletin of Kursk State Agricultural Academy(7), 1-7.

TPP-Inform. (2014, Oct 09). Utverzhdena «dorozhnaya karta» po importozameshcheniyu v sel'skom khozyaystve. Retrieved from TPP-Inform: http://old.tpp-inform.ru/news/17114.html

Received for publication: $\quad 16.04 .2016$

Revision received: $\quad 23.05 .2016$

Accepted for publication: $\quad 10.06 .2016$

\section{How to cite this article?}

Style - APA Sixth Edition:

Eshugova, S. (2016, July 15). Development of the Russian agro-industrial complex. (Z. Čekerevac, Ed.) MEST Journal, 4(2), 77-82. doi:10.12709/mest.04.04.02.08

Style - Chicago Sixteenth Edition:

Eshugova, Svetlana. 2016. "Development of the Russian agro-industrial complex." Edited by Zoran Čekerevac. MEST Journal (MESTE) 4 (2): 77-82. doi:10.12709/mest.04.04.02.08.

Style - GOST Name Sort:

Eshugova Svetlana Development of the Russian agro-industrial complex [Journal] // MEST Journal / ed. Čekerevac Zoran. - Belgrade : MESTE, July 15, 2016. - 2 : Vol. 4. - pp. 77-82.

Style - Harvard Anglia:

Eshugova, S., 2016. Development of the Russian agro-industrial complex. MEST Journal, 15 July, 4(2), pp. 77-82.

Style - ISO 690 Numerical Reference:

Development of the Russian agro-industrial complex. Eshugova, Svetlana. [ed.] Zoran Čekerevac. 2, Belgrade : MESTE, July 15, 2016, MEST Journal, Vol. 4, pp. 77-82 